\title{
Potassium Humate Application and Cutting Immature Flowers affect Soil Properties, Microbial Activity and Jerusalem Artichoke Yield Components Moustafa, Y. M. M. ${ }^{1}$; A. A. Hammam ${ }^{2}$ and S. A. Haddad ${ }^{3}$ \\ ${ }^{1}$ Horticulture Department, Faculty of agriculture, Minia University, Minia, Egypt. \\ ${ }^{2}$ Soil Department, Faculty of agriculture, Minia University, Minia, Egypt. (corresponding author) ( amr_hmam1978@yahoo.com) \\ ${ }^{3}$ Agricultural Microbiology Department, Faculty of agriculture, Minia University, Minia, Egypt.
}

\section{ABSTRACT}

Driven by spreading Jerusalem artichoke (sunchoke) cultivation for increasing food production and to reduce environmental risks of intensive inorganic fertilization, the target of this research is to evaluate the influences of using potassium humate as organic fertilizer on soil properties, microbial activities, and yield components of Jerusalem artichoke and to see if the removal of immature flowers will affect the plant growth. To achieve this target, Jerusalem artichoke tubers were planted in clay loam soil during two successive summer seasons of 2014 and 2015 in the Middle Egypt. Results showed that using potassium humate at a rate of $5 \mathrm{~kg} \mathrm{ha}^{-1}$ in combination with full or half the recommended dose of NPK fertilizers increased the microbial and enzymatic activities in soil and promoted soil fertility which resulted in increasing nutrients uptake, enhancing the vegetative growth and increasing tubers and foliage yields of sunchoke. Also, using potassium humate along with cutting the immature flowers from the sunchoke plants increased the enzymes activities compared to those plants left with flowers until harvesting their tubers. Moreover, using potassium humate plus only $50 \%$ of NPK and/or removal of immature flowers showed the best desirable characteristics comparing to using the expensive full dose of NPK separately. The use of potassium humate as organic fertilizer is recommended to replace partially chemical fertilizer. These findings encourage the economic cultivation of Jerusalem artichoke in Egypt.

Keywords: Sunchoke, Potassium humate, Immature flowers removal, Soil health, Microbial activities

\section{INTRODUCTION}

Jerusalem artichoke (Helianthus tuberosus L.), also known as sunchoke, is native to North America and is a perennial of the Asteraceae (Compositae) family, which includes lettuce and sunflower (Dias et al., 2016). Conventionally, Jerusalem artichoke has been used for human food or animal fodder. For the past two decades, alternative uses have been explored especially for the production of functional food ingredients (inulin, oligofructose and fructose) and biomass crop for ethanol and biogas production. Sunchoke has valuable characteristics over traditionally agronomic crops, including high growth rate, good tolerance to different climate, drought and infertile soils, strong resistance to pests and diseases, with minimum fertilizer requirements (Yang et al., 2015).

In Egypt, to increase the food production for the growing population, NPK chemical fertilizers, pesticides and herbicides have been intensively applied. Soluble NPK chemical fertilizers increase crop yield because plants exploit these nutrients directly or indirectly provided by these inorganic fertilizers. Various undesirable risk effects on the soil ecosystem like soil degradation, loss of biodiversity and groundwater pollution imparted by the unceasing and comprehensive use of chemical fertilizers (Kaur et al., 2008; Chaudhry et al., 2009; Maji et al., 2017). Humic substances (HS) when applied to the soil as a substitution for chemical fertilizers, improves soil physicochemical properties as well as soil microbial activities, which increase plant growth and yield components.

Therefore, the application of HS such as potassium humate has become one of the available choices to rehabilitate the degraded soils. Humic substances is a vital component of soil organic matter and soils devoid from HS are difficult to be sustained fertile even with large applications of synthetic fertilizers. In addition, effects of HS on soil and plant are longer lived than synthetic fertilizers. Humic substances acts as a catalyst to stimulate microbial activity and reduces the adverse influences of agrochemicals in the soil environment. Application of HS in very low concentrations has been reported to enhance plant growth parameters and nutrition status and soil physiochemical properties due to its ability to form complexes with elements suitable for assimilation by plant (Memon and Khetran, 2014). However, limited studies on the effect of HS on microbial and enzymes activity have been made.

The humic substances play an important role in the soil workability and plant nutrition and consider one of the most important soil consistency factors of the life processes and can be a source of nutrients for soil microorganisms (Theunissen et al., 2010). Humic substances are derived from decomposition of organic matter and they also comprise 50 to $90 \%$ of the organic matter of peat and lignite (Shahryari et al., 2009; Memon and Khetran, 2014). Humic substances commercially available in the form of inexpensive soluble salts, referred to as potassium humates and potassium fulvates (Imbufe et al., 2005). Several researches investigated the application of HS as a soil conditioner and plant growth stimulator.

The addition of HS to soils can have important implications on the soil physical, chemical, and biological characteristics. Addition of HS improved aggregation in soils with a range of texture grades and mineral suites (Quilty and Cattle, 2011). Humic substances used as soil application significantly increased N, P, K, Ca, $\mathrm{Mg}, \mathrm{S}, \mathrm{Mn}$ and $\mathrm{Cu}$ contents in shoot of pepper seedling, while $\mathrm{N}, \mathrm{P}, \mathrm{K}, \mathrm{Ca}, \mathrm{S}, \mathrm{Fe}, \mathrm{Mn}, \mathrm{Zn}$ and $\mathrm{Cu}$ contents in root were increased (Çimrin et al., 2010). Interacting with soil microorganisms, HS even in small amounts affect their growth by inhibiting (Loffredo et al., 2007) or stimulating it, due to its capability of defending soil biota against the toxic effect of pollutants (Trevisan et $a l ., 2010)$. Soils with high HS encourage plant growth, making them more adapted, healthier, increasing yields with a larger nutritional quality of harvested foods and feeds (Pettit, 2004).

Despite the actual interest in Jerusalem artichoke, studies that evaluate field performances of this crop are still scarce especially in Egypt. Hence, the aim of this study is to spread the cultivation of this valuable crop in the Middle Egypt (El-Minia region). To achieve this aim, the specific objectives were: 1) to study the effects of potassium humate as a substitution for NPK chemical fertilizers along with studying the effect of potassium humate on soil properties, microbial activity, and yield components, 2) to study the effects of cutting immature flowers (topping the plants) on growth parameters and yield components. 


\section{MATERIALS AND METHODS}

Experiment research was carried out for two successive seasons of 2014 and 2015 at the Vegetables Scientific Experimental Farm, Horticulture Department, Faculty of agriculture, Minia University, Minia, Egypt. To investigate the effects of potassium humate in combination with NPK chemical fertilizers along with cutting immature flowers on soil fertility, soil enzymatic and microbial properties, plants growth and yield components of sunchoke. The field was well prepared before plantation and the investigated clay loam soil was divided into plots $(3 \times 3.5 \mathrm{~m})$ distributed in a randomized complete block design (RCBD) (six treatments $\times$ three replicates). Jerusalem artichoke tubers (Helianthus tuberosus L., Egyptian clone) was kindly obtained from the Vegetative Propagated Vegetables Department, Egyptian Agricultural Research Center, Giza, Egypt.

In the beginning of April 2014 and 2015, plots consisted of rows (70 cm apart) were planted with sunchoke tubers (seeds) in the middle of each row $(30 \mathrm{~cm}$ apart) and were slightly covered with smooth soil. The recommended NPK fertilizers doses according to the Egyptian Ministry of Agriculture Protocol was used as follow; $350 \mathrm{~kg}$ ammonium nitrate $(33.5 \% \mathrm{~N}), 950 \mathrm{~kg}$ calcium super phosphate $\left(15.5 \% \mathrm{P}_{2} \mathrm{O}_{5}\right)$ and $240 \mathrm{~kg}$ potassium sulfate $\left(48 \% \mathrm{~K}_{2} \mathrm{O}\right)$ per hectare. Potassium humate as a substitution for NPK chemical fertilizers was applied at a rate of $5 \mathrm{~kg} \mathrm{ha}^{-1}$ in combination with full or half recommended doses of NPK fertilizers. Immature flowers were removed or not removed from sunchoke plants just after blooming and before opening to see if the removal of immature flowers will affect plant growth and yield components. Treatments used in both seasons were as follow:

1 - Full dose $(100 \%)$ of NPK.

2- Potassium humate $+100 \%$ of NPK dose.

3- Potassium humate $+50 \%$ of NPK dose.

4- $100 \%$ of NPK + cutting the immature flowers.

5- Potassium humate $+50 \%$ of NPK dose + cutting the immature flowers.

6- Potassium humate $+100 \%$ of NPK dose + cutting the immature flowers.
HUMUS ${ }^{\circledR}$ WSG 90 product of potassium humate was imported and used in this study. This product contains $85 \% \mathrm{~K}$-humate and $10-12 \% \mathrm{~K}_{2} \mathrm{O}$. The product is in powder form and it was dissolved in water for two hours before use as furrow irrigation water. The potassium humate applications were done twice; the first time after tubers plantation and the second after full germination of the tubers (about one month after tubers plantation).

\section{Recorded data}

Data of the plant height $(\mathrm{cm})$, number of branches/plant were recorded just 10 days after cutting immature flowers when plants were fully vegetative grown. The average fresh weight of plants and tubers $(\mathrm{kg})$; (ten plants and their tubers were randomly collected from each replicate) along with number of tubers/plant were recorded after harvesting the sunchoke plants in the beginning of October 2014 and 2015. Average dry weight of the collected plants $(\mathrm{kg})$ was recorded after complete drying of these plants under sunrays in an open sunny place.

\section{Soil and plant analyses}

Soil samples were collected after harvest from the top $20 \mathrm{~cm}$ of soil for analyses. All soil and microbial analyses were carried out in Soil and Microbiology Departments, Faculty of agriculture, Minia University, Minia, Egypt. Soil samples were air dried and ground to pass through a 2-mm sieve for soil chemical properties analyses in accordance with Page, 1982. Standard methods have also been derived from Avery and Bascombe, 1982 and methods of soil analyses (Black et al., 1965). The nutritional status of Jerusalem artichoke plants was checked by determination the content of nutritional elements of NPK in Jerusalem artichoke leaves collected from experimental plots 10 days after cutting immature flowers. Plant leaves were oven dried at $65^{\circ} \mathrm{C}$ and ground, digested using $\mathrm{H}_{2} \mathrm{SO}_{4}$ and $\mathrm{H}_{2} \mathrm{O}_{2}$ and analyzed according to the procedures described by Page, 1982. Soil chemical and physical properties of the investigated farmland soil showed in Table (1).

Table 1. Chemical and physical characteristics of the investigated soil.

\begin{tabular}{lllllllll}
\hline $\begin{array}{l}\text { Particle size distribution \% } \\
\begin{array}{l}\text { Coarse } \\
\text { Sand }\end{array}\end{array}$ & Fine Sand & Silt & Clay & $\begin{array}{c}\text { Soil } \\
\text { texture }\end{array}$ & $\begin{array}{l}\mathbf{C a C O}_{\mathbf{3}} \\
\mathbf{g ~ k g}^{-1}\end{array}$ & $\begin{array}{l}\mathbf{p H} \\
\mathbf{1 : 2 . 5}\end{array}$ & $\begin{array}{l}\mathbf{E C ~ d S m}^{-1} \\
\mathbf{1 : 2 . 5}\end{array}$ & $\begin{array}{l}\mathbf{S O C}^{*} \\
\mathbf{g ~ k g}^{-1}\end{array}$ \\
\hline 7.30 & 28.90 & 27.86 & 35.94 & Clay loam & 32 & 8.04 & 0.52 & 6.0 \\
\hline
\end{tabular}

* SOC: Soil organic carbon

\section{Microbial Biomass $\mathbf{C}$ and $\mathbf{N}$}

Microbial biomass $\left(\mathrm{C}_{\text {mic }}\right)$ was determined by the fumigation-extraction method as described by Vance et al. (1987). The concentration of organic $\mathrm{C}$ in the extract was determined with a carbon analyzer (Shimadzu Model TOC-5050) after acidification with one drop of 2 $\mathrm{M} \mathrm{HCl}$ to remove any dissolved carbonate.

Microbial biomass $\mathrm{N}\left(\mathrm{N}_{\text {mic }}\right)$ was determined by the chloroform fumigation-incubation method described by Horwath and Paul (1994). The $\mathrm{NH}_{4}-\mathrm{N}$ thus extracted was determined in a $20-\mathrm{ml}$ aliquot of the extract by steam distillation (Keeney and Nelson, 1982).

\section{Hydrolasis of enzyme substrates}

Formamide hydrolysis was determined as described by Frankenberger and Tabatabai (1980) for amidase activity, but without buffer or toluene, at $30^{\circ} \mathrm{C}$ for $2 \mathrm{~h}$. The same procedure used for formamide hydrolysis was used for arginine, asparagine, and glutamine hydrolysis, but $50 \mathrm{mM}$ of L-arginine,
L-asparagine, or L-glutamine, respectively, was used as a substrate for arginase, asparaginase, or glutaminase activity (Frankenberger and Tabatabai, 1991a, b).

The hydrolysis of $\rho$-nitrophenyl $-\beta^{-} \mathrm{D}^{-}$glucopyranoside was determined as described by Tabatabai, 1994 and Haddad et al., 2013. The same method used for determination of the rate of hydrolysis of p-nitrophenyl- $\beta$-D-glucopyranoside was used for determination of the hydrolysis of p-nitrophenyl- $\mathrm{N}^{-}$acetyl- $\beta^{-}$D-glucosaminide. All substrate hydrolyses were performed in triplicates and one control using fieldmoist soils expressed on an oven dried basis.

\section{Statistical analyses}

Collected data were subjected to the analysis of variance (ANOVA) and means were compared using the Duncan Multiple Range test and/or the Least Significant Difference (L.S.D.) at $95 \%$ confidence using the MSTATC program Ver. 4.0 (Michigan University, USA) according to Gomez and Gomez (1984). 


\section{RESULTS AND DISCUSSION}

Horticultural characteristics

\section{Vegetative growth parameters (fodder yield)}

The average fresh and dry weights of total vegetative sunchoke plants, used as animal fodder, were $4.22,4.13$ and $1.32,1.29 \mathrm{~kg} / \mathrm{plant}$ in both seasons, respectively. Treating plants with potassium humate and cutting immature flowers plus $50 \%$ or $100 \%$ of NPK increased significantly fresh and dry weights of the plants compared to other treatments (Table 2). Plants received the full dose of NPK, treated with potassium humate and cutting immature flowers showed the highest significant values of plant fresh and dry weights in both seasons, while plants only received the full dose of NPK showed the lowest values of plant fresh weight. Interestingly, plants treated with potassium humate plus $50 \%$ and $100 \%$ of NPK doses gave insignificant different values of plant fresh and dry weights, while those values were less than those obtained from plants treated with potassium humate $+50 \%$ NPK + cutting immature flowers in both seasons. In addition, there were insignificant differences in plant dry weight values of plants only received $100 \%$ of NPK $(1.11$ and $1.03 \mathrm{~kg})$ and those received $50 \%$ of NPK dose but treated with potassium humate $(1.11$ and $0.96 \mathrm{~kg})$ in both seasons, respectively. From this phenomenon, it's clear that potassium humate and removing the immature flowers had a positive effect on both plant fresh and dry weight as they increased the average plant fresh and dry weights and saved $50 \%$ of the chemical fertilizers (NPK) as shown in Table (2).

The average plant height values for all treatments were 2.10 and $2.04 \mathrm{~m}$ in both seasons, respectively. Results of this characteristic was dissimilar to the average plant fresh and dry weight characteristics as treating soil with full dose of NPK with potassium humate without cutting immature flowers increased the heights of sunchoke plants compared to plants with cutting flowers which resulted in shorter plants as shown in Table (2). Plants received $100 \%$ of NPK with potassium humate showed the significant highest values $(2.39$ and $2.30 \mathrm{~m})$, while plants received only $50 \%$ of NPK dose + potassium humate + cutting flowers showed the lowest values in both seasons (1.81 and 1.80 $\mathrm{m})$.

Table 2. Changes in yield components of sunchoke plants grown on clay loam soil (two successive seasons of (2014 - 2015)

\begin{tabular}{|c|c|c|c|c|c|c|c|c|c|c|c|c|c|c|}
\hline & \multicolumn{2}{|c|}{$\begin{array}{c}\text { Plant fresh } \\
\text { weight } \\
\text { (kg) }\end{array}$} & \multicolumn{2}{|c|}{$\begin{array}{c}\text { Plant dry } \\
\text { weight } \\
\text { (kg) }\end{array}$} & \multicolumn{2}{|c|}{$\begin{array}{c}\text { Plant } \\
\text { Height } \\
\text { (m) }\end{array}$} & \multicolumn{2}{|c|}{$\begin{array}{c}\text { No of } \\
\text { branches/ } \\
\text { plant }\end{array}$} & \multicolumn{2}{|c|}{$\begin{array}{c}\text { Fresh } \\
\text { yield/plant } \\
(\mathrm{kg})\end{array}$} & \multicolumn{2}{|c|}{$\begin{array}{l}\text { No of } \\
\text { tubers/ } \\
\text { plant }\end{array}$} & \multicolumn{2}{|c|}{$\begin{array}{l}\text { Single tuber } \\
\text { fresh } \\
\text { weight }(g)\end{array}$} \\
\hline & 2014 & 2015 & 2014 & 2015 & 2014 & 2015 & 2014 & 2015 & 2014 & 2015 & 2014 & 2015 & 2014 & 2015 \\
\hline & & & & & $27 \mathrm{~b}$ & $2.18 \mathrm{ab}$ & $14.00 \mathrm{ab}$ & & & & & & $87.1 \mathrm{c}$ & $7 \mathrm{c}$ \\
\hline & & & & & & & & & & & & & & $9 \mathrm{~b}$ \\
\hline & & & & & & & & & & & & & 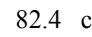 & . \\
\hline & $3.65 \mathrm{~d}$ & & & & d & & $\mathrm{b}$ & & & & & $b$ & $96.8 \mathrm{~b}$ & 1 \\
\hline $\begin{array}{l}\text { Humic acid }+50 \% \text { NPK }+ \\
\text { Cut }\end{array}$ & 4.861 & 4 & 1 & 1 & 1. & $0 \mathrm{c}$ & $9.67 \mathrm{c}$ & & 4 & $\mathrm{c}$ & 3 & $.0 \mathrm{c}$ & $128.8 \mathrm{a}$ & a 1 \\
\hline umic acid $+100 \%$ NPK + & 5 & 5. & & 1, & $2.08 \mathrm{c}$ & $2.15 \mathrm{~b}$ & $14.33 \mathrm{a}$ & $13.33 \mathrm{a}$ & $5.15 \mathrm{a}$ & $5.05 \mathrm{a}$ & $51.67 \mathrm{a}$ & $46.0 \mathrm{~b}$ & $99.8 \mathrm{~b}$ & b 100.2 \\
\hline Mean & 4.22 & 4.13 & 1.32 & 1.29 & 2.10 & 2.04 & 12.11 & 12.39 & 4.04 & 4.04 & 41.28 & 42.50 & 99.61 & 99.65 \\
\hline
\end{tabular}

*Different letters in the same column indicate significant differences $(p<0.05)$ between the treatments

The general average number of branches/plant was 12.11 and 12.39 in both seasons, respectively. Results of this plant characteristic were almost irregular compared to other characteristics. Chemical fertilizers (NPK) increased the number of branches in sunchoke plants fertilized with $100 \%$ NPK either alone or in combination with all treatments (Table 2). The full dose increased number of branches/plant to reach 14.33 in the first season when potassium humate was added to the full dose of NPK and the immature flowers were removed from plants. Also, using NPK only but in full dose gave the same result (14.0) in both seasons. On the contrary, both treatments (potassium humate $+50 \%$ NPK and potassium humate $+50 \%$ NPK + cut) gave lowest values of number of branches/plant (8.76 and 9.67), respectively (Table 2 ).

Fresh tubers yield (kg/plant) and yield components

The treatment with (potassium humate $+100 \%$

NPK + cut) resulted in the highest significant yield of sunchoke plants where fresh tubers were 5.15 and 5.05 $\mathrm{kg} / \mathrm{plant}$ in both seasons, respectively (Table 2). This was followed by (potassium humate $+100 \%$ NPK) in the second season (4.41 kg/plant) followed by the treatment (potassium humate $+50 \% \mathrm{NPK}+$ cut) in the first season $(4.07 \mathrm{~kg} / \mathrm{plant})$. On the other hand, the treatment (potassium humate $+50 \% \mathrm{NPK}$ ) produced lowest fresh yield of tubers/plant (3.58 and 3.67 $\mathrm{kg} /$ plant), but interestingly it was similar to the treatment $(100 \% \mathrm{NPK})$ which gave (3.57 and 3.67 $\mathrm{kg} /$ plant) in both seasons.

Moreover, it is clear from the results of this characteristic that removing the immature flowers from the sunchoke plants increased the fresh tubers yield compared to plants left with flowers until harvesting (Table 2). Cutting immature flowers promoted much growth of sunchoke plants by stimulating lateral shoots and root growth, thus may be improved soil microbial activity which reflected in increasing soil nutrient availability. Treating plants with (potassium humate + $100 \%$ NPK + cut) in the first season and (potassium humate $+100 \%$ NPK) in the second season resulted in the highest number of fresh tubers/plant (51.67 and 54.0 , respectively), followed by all treatments included the full dose of NPK (Table 2). On the other hand, the treatment (potassium humate $+50 \% \mathrm{NPK}+$ cut) gave the lowest values of number of fresh tubers/plant in both seasons (31.67 and 33.0). It has been stated that potassium humate produces plant hormones or growth regulators that may affect plant growth (Yang et al., 2004).

As shown in Table (2), the treatment (potassium humate $+50 \%$ NPK + cut) resulted in the highest values of single tuber fresh weight (128.8 and $120.2 \mathrm{~g}$ ) in both seasons, respectively, followed by the treatment 


\section{Moustafa, Y. M. M. et al.}

(potassium humate $+50 \% \mathrm{NPK}$ ) in both seasons, too (102.7 and $102.9 \mathrm{~g}$, respectively). The treatment (potassium humate $+100 \% \mathrm{NPK}+$ cut) which gave the highest values of number of tubers/plant gave tubers with moderate weights in both seasons (99.8 and 100.2 g). Moreover, when the full dose of NPK was used alone or combined with potassium humate without cutting immature flowers, resulted in the lowest values of average single tuber weights in both seasons (87.1 and $86.7 \mathrm{~g})$ and $(82.4$ and $81.0 \mathrm{~g})$ respectively. This phenomenon means that potassium humate and cutting immature flowers have great impact on plant growth as they increased number of tubers and the average single tuber weights as shown in Table (2). Potassium humates may stimulate shoot and root growth, and improve resistance to environmental stress in plant (Shahryari et al., 2009).

\section{Clarification of Soil properties}

Results of this research showed that treating soil with potassium humate in combination with full or half dose of NPK fertilizers with cutting or not immature flowers significantly increased SOC, available NPK and decreased soil EC compared to plants treated with NPK alone. These studied treatments however insignificantly decreased soil pH (Table 3), and this might be due to the relatively high buffering capacity of the studied soil. Plants received the full dose of NPK, treated with potassium humate and their immature flowers were cut showed the highest significant values of these soil chemical properties. These phenomena mean potassium humate and cutting immature flowers have impressive impact upon soil chemical properties and consequently increased plant growth parameters as they increased the average plant NPK uptake, plant fresh and dry weights and sunchoke yield.
There was a significant increase in SOC $\left(\mathrm{g} \mathrm{kg}^{-1}\right)$ with potassium humate in combination with half recommended dose of NPK without immature flowers cutting $\left(7.3 \mathrm{~g} \mathrm{~kg}^{-1}\right)$ and potassium humate $+50 \% \mathrm{NPK}+$ Cut $\left(7.5 \mathrm{~g} \mathrm{~kg}^{-1}\right)$ treated plots compared to treatments of $100 \%$ NPK $\left(6.1 \mathrm{~g} \mathrm{~kg}^{-1}\right)$ and $100 \%$ NPK + Cut $(6.2 \mathrm{~g}$ $\left.\mathrm{kg}^{-1}\right)$ plots. Additionally, soil plots treated with potassium humate in combination with half recommended dose of NPK with or without immature flowers cutting caused a significant increase in SOC\% in comparison with those treated with potassium humate in combination with full recommended dose of NPK with or without immature flowers cutting. The potassium humate in combination with either $75 \%$ or $100 \%$ of the recommended dose of NPK had an effect on SOC of the soil in alfisol and inceptisol (Bama et al., 2008).

Potassium humate incorporated into the soil investigated significantly improved some soil chemical properties and insignificantly and slightly decreased soil $\mathrm{pH}$, which is a positive effect in terms of nutrient availability in alkaline soils (Table 3). As with potassium humate addition in this study, the soil organic carbon (SOC) of soil increases in proportion to the amount of humic acid as organic matter, thereby increasing nutrient availability for sunchoke plant uptake and microbial biomass and thus increased soil fertility. Differences in soil carbon availability affect soil health, structure and microbial biomass with elevated concentrations (Truu, et al., 2008). Changes in soil chemical, physical and biological properties as a result of organic matter addition are considered as important factors of soil quality and land uses impacts in numerous studies (Stores et al., 2005; Truu et al., 2008, Madejon et al., 2009).

Table 3. Changes in soil chemical properties after two seasons of cultivation.

\begin{tabular}{|c|c|c|c|c|c|c|}
\hline Treatments & $\mathbf{p H}$ & $\begin{array}{c}\mathrm{EC} \\
\mathrm{dSm}^{-1}\end{array}$ & $\begin{array}{c}\text { SOC } \\
\text { g kg-1 }\end{array}$ & $\begin{array}{c}\text { Available } \mathbf{N} \\
\mathrm{mg} \mathrm{Kg}^{-1}\end{array}$ & $\begin{array}{c}\text { Available P } \\
\mathrm{mg} \mathrm{Kg}^{-1} \\
\end{array}$ & $\begin{array}{c}\text { Available K } \\
\mathrm{mg} \mathrm{Kg}^{-1}\end{array}$ \\
\hline $100 \% \mathrm{NPK}$ & $8.04 \mathrm{a}^{*}$ & $0.54 \mathrm{~b}$ & $6.1 \mathrm{c}$ & $60.0 \mathrm{~b}$ & $7.43 \mathrm{c}$ & $226.4 \mathrm{c}$ \\
\hline Potassium humate $+50 \%$ NPK & $7.94 \mathrm{a}$ & $0.41 \mathrm{e}$ & $7.3 \mathrm{a}$ & $64.8 \mathrm{ab}$ & $7.98 \mathrm{bc}$ & $236.1 \mathrm{c}$ \\
\hline Potassium humate $+100 \%$ NPK & $7.95 \mathrm{a}$ & $0.46 \mathrm{~d}$ & $6.9 \mathrm{~b}$ & $66.8 \mathrm{ab}$ & $8.31 \mathrm{abc}$ & $241.5 \mathrm{bc}$ \\
\hline $100 \% \mathrm{NPK}+\mathrm{Cut}$ & $8.00 \mathrm{a}$ & $0.63 \mathrm{a}$ & $6.2 \mathrm{c}$ & $59.6 \mathrm{~b}$ & $7.32 \mathrm{c}$ & $226.2 \mathrm{c}$ \\
\hline Potassium humate $+50 \% \mathrm{NPK}+\mathrm{Cut}$ & $7.92 \mathrm{a}$ & $0.45 \mathrm{~d}$ & $7.5 \mathrm{a}$ & $74.5 \mathrm{a}$ & $9.45 \mathrm{a}$ & $262.3 \mathrm{a}$ \\
\hline Potassium humate $+100 \%$ NPK + Cut & $7.94 \mathrm{a}$ & $0.47 \mathrm{c}$ & $7.0 \mathrm{~b}$ & $73.5 \mathrm{a}$ & $9.11 \mathrm{ab}$ & $257.1 \mathrm{ab}$ \\
\hline
\end{tabular}

*Different letters in the same column indicate significant differences $(\mathrm{p}<0.05)$ between the treatments

Humic substances such as potassium humate, fulvic acid, are the major components $(65-70 \%)$ of soil organic matter, increase plant growth enormously due to increasing cell membrane permeability, respiration, photosynthesis, oxygen and phosphorus uptake, and supplying root cell growth (Russo and Berlyn, 1990). Many field experiments indicated that the combined application of $100 \%$ NPK along with foliar spray of humic at the rate of $0.2 \%$ was significantly superior in increasing the yield and nutrients uptake by plants (Elayaraja et al., 2011). Many investigators indicated that potassium humate as an organic fertilizer could be applied as fertilizers, conditioners or both together. Potassium humate materials increase soil organic matter, and hence improve the physical, chemical and biological properties. Consequently, the availability of nutrients for plants as well as soil characteristics should be improved, El-Ghozoli (2003) on faba bean plants; El-
Ghanam and El-Ghozoli (2006); Sayed et al., (2004) on valencia orange and Karakurt et al. (2009) on pepper.

\section{Soil and plant nutrients status}

Potassium humate treatments either with half or full recommended dose of NPK with immature flowers cutting caused a significant increase in available $\mathrm{N}$, available $\mathrm{P}$ and $\mathrm{K}$ in comparison with $100 \%$ NPK and $100 \%$ NPK + Cut treatments. However, there was no significant difference among $100 \%$ NPK, $100 \%$ NPK + Cut, potassium humate $+50 \% \mathrm{NPK}$ and potassium humate $+100 \%$ NPK treatments. Soluble N was increased from 60 and $59.6 \mathrm{mg} \mathrm{Kg}^{-1}$ in plots with $100 \%$ NPK and $100 \% \mathrm{NPK}+$ Cut to 74.5 and $73.5 \mathrm{mg} \mathrm{Kg}^{-1}$ in plots treated with potassium humate in combination with half/full recommended dose of NPK with immature flowers cutting, respectively, Table (3). Furthermore, there was no significant difference within treatments with potassium humate in combination with 
half/full recommended dose of NPK with/without imimmature flowers cutting. The results obtained showed that available phosphorus was significantly increased with potassium humate treatment in combination with half recommended dose of NPK with immature flowers cutting in comparison with the same treatment without immature flowers cutting. On the other hand, no significant difference in available $\mathrm{P}$ was noticed between soil treated with potassium humate in combination with half/full recommended dose of NPK with immature flowers cutting and potassium humate treatment in combination with half recommended dose of NPK without immature flowers cutting.

Humic substances have high cation exchange capacity, therefore potassium humates can form chelates with elements in soils. Humic substances may hold the existing and applied soil nutrients and consequently enrich plant growth (Şahin et al., 2014). David et al. (1994) has reported that, promoted growth and nutrient uptake of plants was due to the addition of HS, which made plants take more mineral elements as a result of better-developed root systems. In addition, the stimulation of ions uptake in the applications of humic materials led many investigators to proposing that these materials affect membrane permeability (Zientara, 1983). This is related to the surface activity of HS resulting from the presence of both hydrophilic and hydrophobic sites (Chen and Schnitzer 1978). Available $\mathrm{K}$ was significantly higher in soil plots treated with potassium humate in combination with half recommended dose of NPK with immature flowers cutting (262.3 mg Kg$\left.{ }^{-1}\right)$ than in soil plots treated with potassium humate in combination with half/full recommended dose of NPK without immature flowers cutting (236.1 and $241.5 \mathrm{mgKg}^{-1}$ ). However, there was no significant difference between plots treated with potassium humate in combination with half/full recommended dose of NPK with immature flowers cutting. Potassium humate incorporated into soil investigated caused significant improvements in NPK uptake by plant and so increased NPK concentrations of sunchoke plants across all studied treatments as shown in Table (4).

Potassium humate has beneficial effects on nutrient uptake by plants and was particularly important for transportation and availability of micro nutrient (Böhme and Thi Lua, 1997). Some studies reported that potassium humate can be used as a growth regulator to regulate hormone level, improve plant growth and enhance stress tolerance (Piccolo et al., 1992). Potassium humate not only increased macro-nutrient contents, but also enhanced micro-nutrient contents of plant organs (Turkmen et al., 2004). The high solubility of potassium humate in water affect the components of pore liquid causing changes in their physical properties, consequently influencing soil chemical and biological properties (Ling-Ling Zeng et al., 2016).

Table 4. Plant nutrients status after two seasons of cultivation.

\begin{tabular}{lcccccc}
\hline \multirow{2}{*}{ Treatments } & \multirow{2}{*}{ N (\%) } & \multirow{2}{*}{$\mathbf{P}(\%)$} & \multirow{2}{*}{ K (\%) } & \multicolumn{3}{c}{ Plant uptake (g/plant) } \\
\cline { 5 - 7 } & & & $\mathbf{N}$ & $\mathbf{P}$ & $\mathbf{K}$ \\
\hline $100 \%$ NPK & $1.83 \mathrm{~d}$ & $0.30 \mathrm{~d}$ & $1.64 \mathrm{~d}$ & $1.89 \mathrm{~d}$ & $0.31 \mathrm{~d}$ & $1.69 \mathrm{~d}$ \\
Potassium humate + 50\% NPK & $1.81 \mathrm{~d}$ & $0.30 \mathrm{~d}$ & $1.61 \mathrm{~d}$ & $1.74 \mathrm{e}$ & $0.29 \mathrm{~d}$ & $1.55 \mathrm{e}$ \\
Potassium humate + 100\% NPK & $1.96 \mathrm{c}$ & $0.32 \mathrm{bc}$ & $1.73 \mathrm{c}$ & $2.55 \mathrm{c}$ & $0.41 \mathrm{c}$ & $2.25 \mathrm{c}$ \\
$100 \%$ NPK + Cut & $2.05 \mathrm{~b}$ & $0.33 \mathrm{ab}$ & $1.84 \mathrm{~b}$ & $2.46 \mathrm{c}$ & $0.40 \mathrm{c}$ & $2.21 \mathrm{c}$ \\
Potassium humate + 50\% NPK + Cut & $2.06 \mathrm{~b}$ & $0.31 \mathrm{~cd}$ & $1.75 \mathrm{c}$ & $3.34 \mathrm{~b}$ & $0.50 \mathrm{~b}$ & $2.84 \mathrm{~b}$ \\
Potassium humate + 100\% NPK + Cut & $2.30 \mathrm{a}$ & $0.34 \mathrm{a}$ & $2.00 \mathrm{a}$ & $3.80 \mathrm{a}$ & $0.56 \mathrm{a}$ & $3.30 \mathrm{a}$ \\
\hline
\end{tabular}

*Different letters in the same column indicate significant differences $(p<0.05)$ between the treatments

\section{Microbial biomass Carbon and Nitrogen:}

Results of this research showed that using potassium humate in combination with full or half dose of NPK fertilizers significantly increased microbial biomass $\mathrm{C}\left(\mathrm{C}_{\mathrm{mic}}\right)$. The $\mathrm{C}_{\text {mic }}$ values ranged from 98.3 to $204 \mathrm{mg} \mathrm{kg}^{-1}$ of soil in full dose $(100 \%)$ of NPK and potassium humate $+100 \%$ of NPK dose + cutting the immature flowers respectively, demonstrating significant variations across treatments. The highest significant soil microbial biomass $\mathrm{C}$ was obtained with potassium humate $+100 \%$ of NPK dose + cutting the immature flowers, followed by the potassium humate + $50 \%$ of NPK dose + cutting the immature flowers and potassium humate $+50 \%$ of NPK dose, respectively (Fig. 1). Microbial biomass $\mathrm{C}$ and $\mathrm{N}\left(\mathrm{C}_{\text {mic }}\right.$ and $\left.\mathrm{N}_{\text {mic }}\right)$ are the most important biochemical pools that affect the nitrogen mineralization process in soils, and early indicator of changes in total soil organic carbon.

Using chemical NPK fertilizers alone led to a significant reduction in $\mathrm{C}_{\text {mic }}$ compared to NPK fertilizers plus humate with cutting or not immature flowers. Actually, the soil organic carbon (SOC) level due to inorganic fertilizers addition was almost nil. In contrast, the stock of readily metabolizable $\mathrm{C}$ in potassium humate is expected to have been the most influential factor contributing to the $\mathrm{C}_{\text {mic }}$ measured. $\mathrm{C}_{\text {mic }}$ accumulated at lower levels in the case of using chemical fertilizers of NPK alone was due to lowering levels of microbial biomass by the inorganic $\mathrm{N}$ fertilizer (Wang et al., 2008; Fang et al., 2009). Wallenstein et al., (2006) stated that inorganic $\mathrm{N}$ addition lowered $\mathrm{C}_{\text {mic }}$ by $40-59 \%$ and $\mathrm{C}_{\text {mic }}$ had negative relationships with total $\mathrm{N}$ inputs in both mineral and organic soils.

In contrast, chemical fertilizers of NPK added to soil alone significantly increased $\mathrm{N}_{\text {mic }}$ levels compared with using potassium humate in combination with full or half dose of NPK fertilizers either immature flowers removed or not. This was due to the availability of $\mathrm{N}$ increased after inorganic $\mathrm{N}$ fertilizers additions and so microbes immobilized $\mathrm{N}$ (Wang et al., 2008). The $\mathrm{N}_{\text {mic }}$ values decreased from 43.9 to $14.6 \mathrm{mg} \mathrm{kg}^{-1}$ of soil in full dose $(100 \%)$ chemical fertilizers of NPK alone plus cutting the immature flowers and potassium humate + $100 \%$ of NPK dose plus cutting the immature flowers, respectively. Similar trends were obtained between the ratios of $\mathrm{C}_{\text {mic }}: \mathrm{N}_{\text {mic }}$ where the lower ratios were observed in treatments involving chemical fertilizers of NPK alone compared to humate treatments. The $\mathrm{C}: \mathrm{N}$ ratios of the microbial biomass $\mathrm{C}_{\mathrm{mic}}$ and $\mathrm{N}_{\text {mic }}$ ranged from 2.3 in full dose $(100 \%)$ of NPK to 9.4 in the potassium humate $+50 \%$ of NPK dose + cutting the immature flowers. In this research, the effect of other inorganic fertilizers of $P$ and $\mathrm{K}$ used apart from $\mathrm{N}$ on soil microbial biomass has largely been regarded as insignificant (Allen and Schlesinger, 2004). 
Moustafa, Y. M. M. et al.
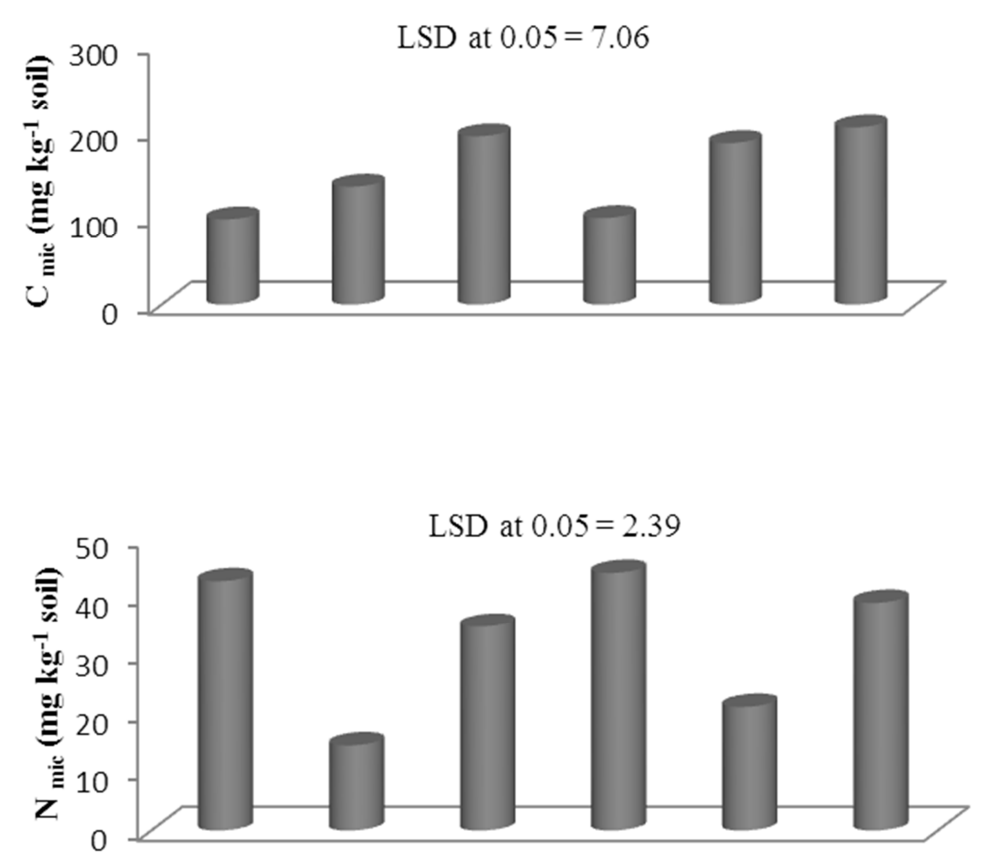

LSD at $0.05=0.54$

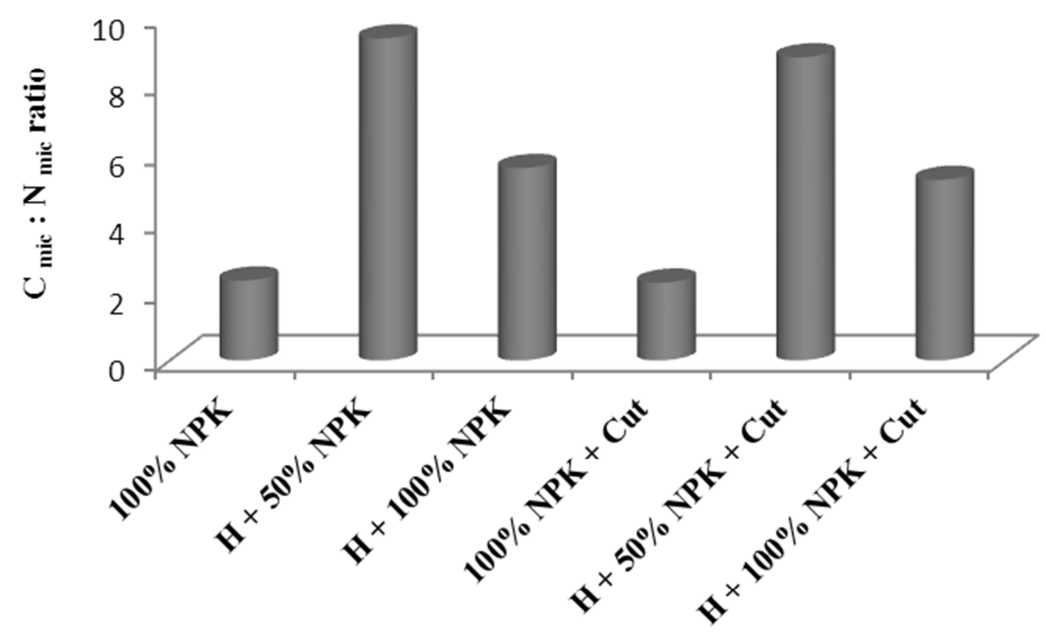

Fig. 1 Soil microbial biomass under various chemical NPK fertilizers plus potassium humate combinations.

Enzymes activity:

In this study, the treatment with (potassium humate $+100 \% \mathrm{NPK}+$ cut) resulted in the significant in crease of all specific enzymes hydrolysis. This was followed by (potassium humate $+50 \% \mathrm{NPK}+$ cut) and (potassium humate $+100 \%$ NPK) respectively (Fig. 2). Moreover, it is clear from the results that using potassi um humate and cutting the immature flowers from the sunchoke plants increased the enzymes activities compared to those plants left with flowers until harvesting their tubers. This presumably was because a greater proportion from the minerals and nutrients went to the root zone, hence, with the availability of nutrients in the rhizosphere, the microbial population and activity will be increased and thus increased the enzymatic activity also. Hydrolysis of several substrates in soils can be used for estimation of microbial biomass, enzyme activities have been suggested as early indicators of changes in soil properties, because of their rapid response to change in management practices, their relationship to soil biology, and the ease and accuracy of the assay (Dick and Tabatabai, 1993).

Microbial biomass $\mathrm{C}$ and $\mathrm{N}$ are the most important biochemical pools that affect the nitrogen mineralization process in soils, and early indicator of changes in total soil organic carbon (Haddad et al., 
2013). Humic substances are the largest constituent of soil organic matter $(\sim 60 \%)$ and are considered as a key component of the terrestrial ecosystem, being responsible for many complex chemical reactions in soil (Stevenson, 1994). As potassium humate addition in this study, led to an increase in SOC and decrease in soil $\mathrm{pH}$ and consequently increased soil microbial activity which in turn increase nutrients solubility for plant uptake. Nowadays, for sustainable agriculture, the use of potassium humate as organic soil fertilizer is recommended to replace chemical fertilizer. Results of this study indicated that using combinations of potassium humate and half recommended levels of NPK fertilizers with the removal of immature artichoke

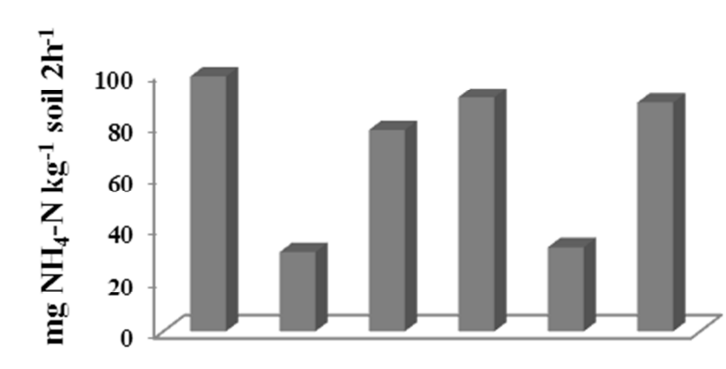

Amidase LSD at $0.05=6.82$

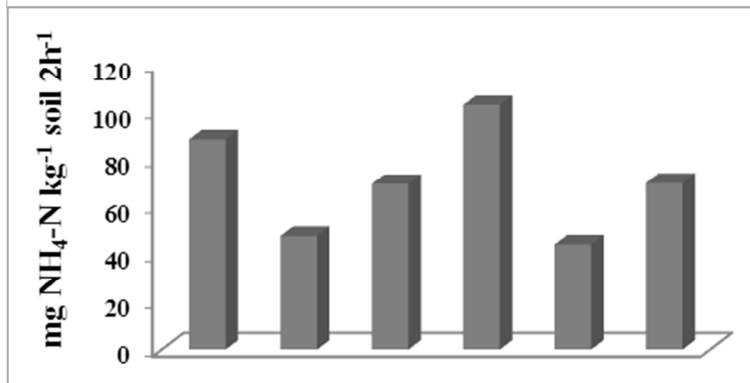

Asparaginase LSD at $0.05=2.63$

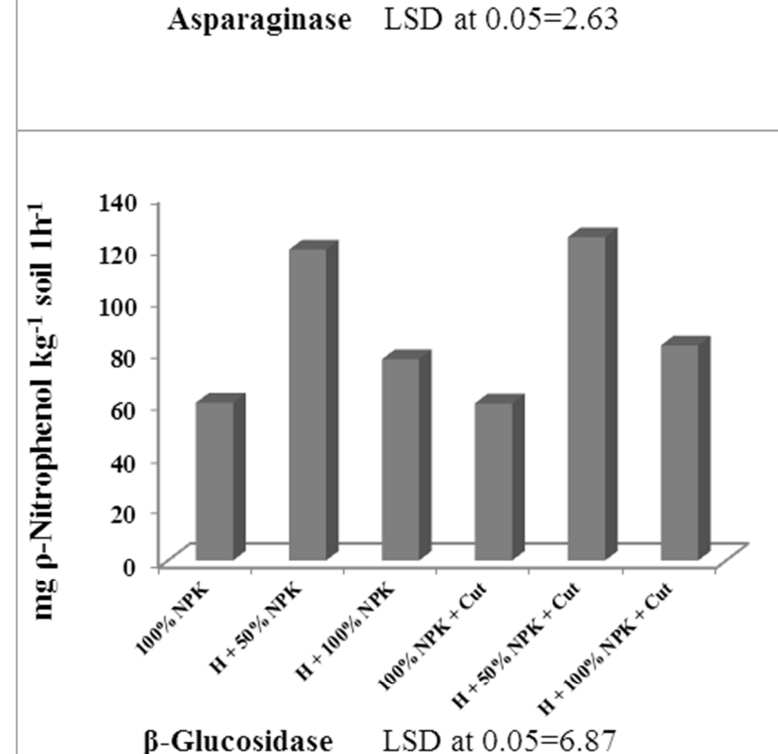

Fig. 2. Enzymes activities in soil under various chemical

Results of this study indicated that soils treated with potassium humate in combination with chemical flowers had improved significantly soil fertility, induced active biological soil conditions for enzymatic and microbial activities and consequently stimulated all artichoke plant trait qualities. In addition, increasing microbial populations resulting from potassium humate addition to soils may have influenced plant growth indirectly by increasing elements mineralization.

The mechanism by which humic substance influence enzyme activities is still not completely understood. Several hypotheses have been suggested. The effect of addition of potassium humate was strong enough to produce significant results on the enzymes activity (Piccolo et al., 1996).

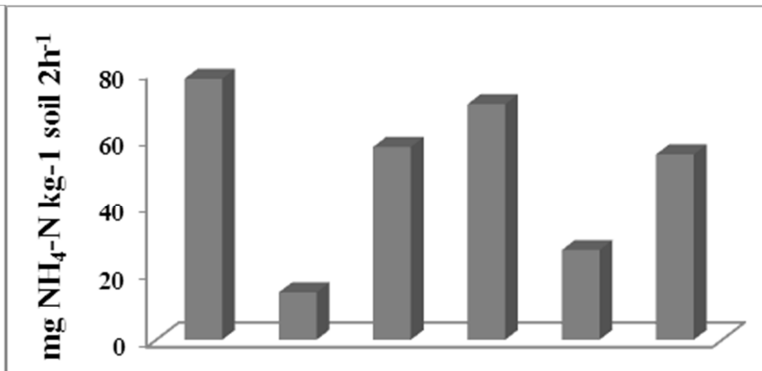

Arginase LSD at $0.05=1.31$

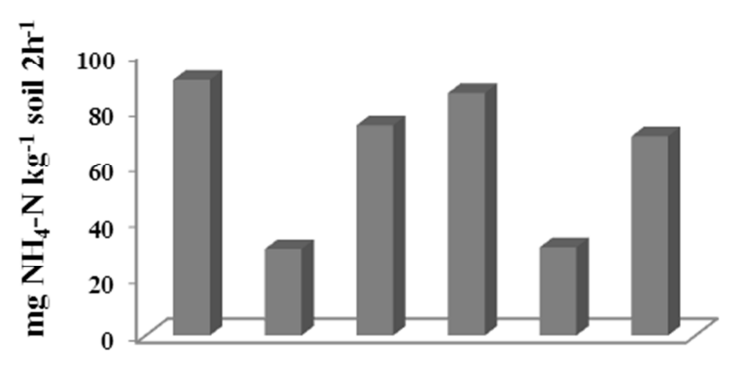

Glutaminase $\quad$ LSD at $0.05=2.22$

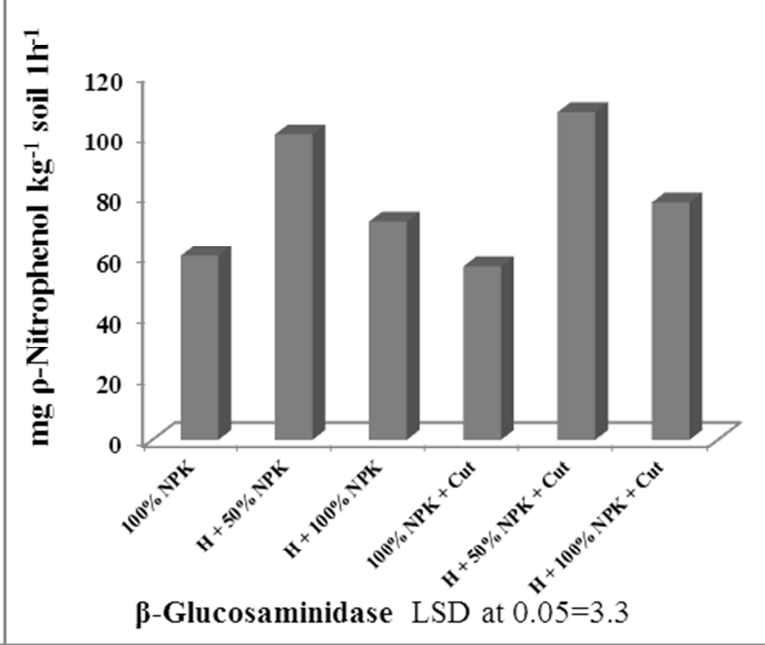

NPK fertilizers plus potassium humate combinations fertilizers of NPK had a significantly greater enzymatic and microbial activities than soils that received chemical NPK fertilizers alone. There are substantial 
evidences demonstrating that microorganisms, including bacteria, fungi, yeasts, actinomycetes and algae resulting from potassium humate are capable of producing plant growth regulators (PGRs) such as auxins, gibberellins, cytokinins, ethylene and abscisic acid in appreciable quantities (Frankenberger and Arshad, 1995).

\section{CONCLUSION}

The present study concludes that treated soil with potassium humate in combination with full dose of NPK chemical fertilizers and cutting immature sunchoke flowers almost gave the highest values of yield components of sunchoke. On the other hand, using just $50 \%$ of NPK recommended dose in combination with potassium humate with cutting immature sunchoke flowers caused the best positive changes in soil physiochemical properties, enzymatic and microbial activities and consequently plant growth parameters as using full NPK recommended dose.

\section{REFERENCES}

Allen, A.S. and Schlesinger, W.H. (2004). Nutrient limitations to soil microbial biomass and activity in loblolly pine forests. Soil Biology \& Biochemistry, (36) 581-589.

Avery, B. W. and Bascomb, C. L. (1982). Soil survey laboratory methods. Technical Monograph No. 6. Soil Survey, Harpenden, UK.

Bama, S., Somasundaram K., Shanmugasundaram, S. P., Kandasamy, G. S. and Thangamuthu, T. J. (2008). Maintenance of soil quality parameters through humic acid application in an Alfisol and Inceptisol. Poster At: Cultivating The Future Based On Science: 2nd Conference Of The International Society Of Organic Agriculture Research ISOFAR, Modena, Italy, June 18-20, 2008.

Black, C. A., Evans, D. D., White, J. L., Ensminger, L. E. and Clark, F. E. (Eds.). (1965). Methods of Soil Analysis. Am. Soc. of Agron. Inc. Madison, Wisconson, USA, $5^{\text {th }}$ ed, 1979.

Böhme M. and Thi Lua H. (1997). Influence of mineral and organic treatments in the rizosphere on the growth of tomato plants. Acta Hortic. 450: 161168.

Chaudhry, A. N., Jilani, G., Khan, M. A. and Iqbal, T. (2009). Improved processing of poultry litter to reduce nitrate leaching and enhance its fertilizer quality. Asian J. Chem. 21, 4997-5003.

Chen, Y. and Schnitzer, M. (1978): Water surface tension of aqueous solutions of soil humic substances. Soil Science, 125: 7-15.

Çimrin, K. M., Türkmen, Ö., Turan, M. and Tuncer, B. (2010). Phosphorus and humic acid application alleviate salinity stress of pepper seedling. African Journal of Biotechnology Vol. 9(36), pp. 5845-5851

David, P. P., Nelson, P.V. and Sanders, D. C. (1994): A humic acid improves growth of tomato seedling in solution culture. Journal of Plant Nutrition, 17: 173-184

Dick, W. A. and Tabatabai, M. A. (1993). Significance and potential uses of soil enzymes. In: F.B. Metting, Jr., editor, Soil microbial ecology: Application in agriculture and environmental management. Marcel Dekker, New York. p. 95127.
Elayaraja, D., Vetriselvan, R. and Dhanasekaran, K. (2011). Effect of NPK levels and different humic acid formulations on the growth, yield and nutrients uptake by bhendi. International research journal of chemistry. (IRJC) .http://irjc.petsd. org. p. 19-28

El-Ghozoli, M. A. (2003). Influence of humic acid on faba bean plants grown in cadmium polluted soil. Annals of Agric. Sci., Moshtohor,.41 (4): 1787 1800 .

Frankenberger, W. T. and M. Arshad. 1995. Phytohormones in Soil: Microbial production and function.Marcel Dekker, New York. 503.

Frankenberger, W. T. and Tabatabai, M.A., 1980. Amidase activity in soils. I. Method of assay. Soil Sci. Soc. Am. 44, 282-287.

Frankenberger, W. T. and Tabatabai, M. A., 1991a. Factors affecting L-asparaginase activity in soils. Biol. Fertil. Soils. 11, 15.

Frankenberger, W. T. and Tabatabai, M. A., 1991b. Factors affecting L-glutaminase activity in soils. Soil Biol. Biochem. 23, 875879.

Gomez K. A and Gomez, A. A. 1984. Statistical procedures for agricultural research. $2^{\text {nd }}$ ed. International Rice Research Institute. Wiley Interscience Publication.John Wiley and Sons. New York.

Haddad S. A., Tabatabai M. A. and Loynachan T. E. (2013). Biochemical processes controlling soil nitrogen mineralization under waterlogged conditions. Soil Sci. Soc. Am. J.77: 809-816.

Horwath, W. R. and Paul, E. A. (1994). Microbial biomass. In: Weaver, R.W., Angel, G.S., Bottomley, P.S. (Eds.), Methods of soil analysis, part 2. Soil Science Society of America, Madison. WI, pp. 753-773.

Imbufe, A. U., Patti, A. F., Burrow, D., Surapaneni, A., Jackson, W. R. and Milner, A. D. (2005). Effects of potassium humate on aggregate stability of two soils from Victoria, Australia. Geoderma $125,321-330$.

Karakurt, Y., Unlu, H., Unlu, H., and H. Padem. (2009). The influence of foliar and soil fertilization of potassium humate on yield and quality of pepper. Acta Agriculturae Scandinavica. 59 (3): 233.

Kaur, T., Brar, B. and Dhillon, N. (2008). Soil organic matter dynamics as affected by long-term use of organic and inorganic fertilizers under maizewheat cropping system. Nutr. Cycl. Agroecosyst. $81,59-61$.

Keeney, D. R. and Nelson, D. W. 1982. Nitrogeninorganic forms. In: Page, A.L., Miller, R.H., Keeney, D. (Eds.), Methods of Soil Analysis, Part 2. Chemical and Micro-biological Properties. Agronomy Monograph 9, 2nd ed. Agronomy Society of America, Madison, WI, USA, pp. 643-698.

Zeng, L., Hong, Z., Wangc, C. and Yang, Z. (2016). Experimental study on physical properties of clays with organic matter soluble and insoluble in water. Applied Clay Science 132-133.

Loffredo, E., Mariagrazia, B., Fedele, C. and Nicola, S. (2007). In vitro assessment of the inhibition of humic substances on the growth of two strains of Fusarium oxysporum. Cooperating Journal of international society of soil science, 1: 1-18.

Madejon, E., Murillo, J. M., Moreno, F., Lopez, M. V., Arrue, J. L., Alvaro-Fuentes, J. and Cantero, C. (2009). Effect of long-term conservation tillage on soil biochemical properties in Mediterranean Spanish areas. Soil \& Tillage Research 105 (1), $55-62$. 
Maji, D., Misra, P., Singh, S. and Kalra, A. (2017). Humic acid rich vermicompost promotes plant growth by improving microbial community structure of soil as well as root nodulation and mycorrhizal colonization in the roots of Pisum sativum Applied Soil Ecology 110 (2017) 97108

Memon, S. A. and Khetran, K. (2014). Effect of humic acid and calcium chloride on the growth and flower production of Snapdragon (Antirrhinum majus). Journal of Agricultural Technology 10(6):1557-1569.

Page, A. L. (1982). Methods of soil analysis, Agron. 9 part 2: physical and mineralogical properties, $2^{\text {nd }}$ ed. Am. Soc. Agron., Wisc. USA.

Pettit, R. E. (2004). Organic matter, humus, humate, humic acid, fulvic acid and humin: their importance in soil fertility and plant health. CTI Research. 1-15.

Piccolo, A., Nardi, S. and Concheri, G. (1992). Structural characteristics of humic substances as regulated to nitrate uptake and growth regulation in plant systems. Soil Biol. Biochem., 24: 373380 .

Piccolo, A., Nardia S. and Concheria G. (1996). Macromolecular changes of humic substances induced by interaction with organic acids. European Journal of Soil Science, 47: 319-328

Quilty, J. and S. Cattle. 2011. Use and understanding of organic amendments in australian agriculture: A Review. Soil Research 49 (1): 1-26.

Russo, R. O. and Berlyn, G. P. (1990). The use of organic biostimulants to help low input sustainable agriculture. J. Sust. Agric. 1: 19-42.

Şahin, S., Karaman, M. R. and Gebologlu, N. (2014). The effects of humic acid application upon the phosphorus uptake of the tomato plant (Lycopersicum esculentum L.). Academic Journals 9(12), 586-590.

Sayed, R. A., Solaiman, B. M. and Abo-El-Komsan E. O. (2004). Effect of foliar sprays of some mineral nutrients, $\mathrm{GA}_{3}$ and/or biostimulant on Yield and fruit quality of Valencia orange trees grown in sandy soil. Egypt. J. Appl. Sci., 19(5): 222-238.

Shahryari, R., Gadimov, A., Gurbanov, E. and Valizade, M. (2009). Applications of potassium humate to wheat for organic agriculture in Iran. As. J. Food Ag-Ind. Special Issue, S164-S168.

Stevenson, F. J. (1994). Humus Chemistry: Genesis, Composition, Reactions. John Wiley \& Sons, $2^{\text {nd }}$ Ed. New York.
Tabatabai, M.A. (1994). Soil enzymes. In: Weaver, R.W., Angle, J.S., Bottomley, P.S. (Eds.), Methods of Soil Analysis. Part II: Microbiological and Biochemical.

Theunissen, J., Ndakidemi, P. A. and Laubscher, C. P. (2010). Potential of vermicompost produced from plant waste on the growth and nutrient status in vegetable production (Review). International Journal of the Physical Sciences Vol. 5(13), pp. 1964-1973.

Trevisan, S., Francioso, O., Quaggiotti, S. and Nardi, S. (2010). Humic substances biological activity at the plant-soil interface: From environmental aspects to molecular factors. Plant Signal. Behav., 5(6), 635-643.

Truu, M., Truu, J. and Ivask, M. (2008). Soil microbiological and biochemical properties for assessing the effect of agricultural management practices in Estonian cultivated soils. European journal of soil biology, (44) $231-237$.

Turkmen, O., Dursun, A., Turan, M., and Erdinc, C. (2004). Calcium and humic acid affect seed germination, growth, and nutrient content of tomato (Lycopersicon esculentum L.) seedlings under saline soil conditions. Acta Agriculturae Scandinavica, Section B, Soil and Plant Science, 54, 168-174.

Vance, E. D., Brookes, P. C., Jenkinson, D. S., (1987). An extraction method for measuring soil microbial biomass C. Soil Biol. Biochem. 19, 703-707.

Wallenstein, M. D., McNulty, S., Fernandez, I. J., Boggs, J. and Schlesinger, W. H. (2006). Nitrogen fertilization decreases forest soil fungal and bacterial biomass in three long-term experiments. Forest Ecology and Management 222, 459-468.

Wang, M. C., Liua, Y. H., Wang, Q., Gong, M., Hua, X. M, Pang, Y. J., Hu, S. and Yang, Y. H. (2008). Impacts of methamidophos on the biochemical, catabolic, and genetic characteristics of soil microbial communities. Soil Biology \& Biochemistry 40, 778-788.

Yang, C. M., Wang, M. H., Lu, Y. F., Chang, I. F. and Chou, C. H. (2004). Humic substances affect the activity of chlorophyllase. J. Chem. Ecol., Vol. 30(5), pp. 1057-1065.

Yang, L., He, Q. S., Corscadden, K. and Udenigwe C. C. (2015). The prospects of Jerusalem artichoke in functional food ingredients and bioenergy production. Biotechnology Reports 5 (2015) 7788.

Zientara, M. (1983). Effect of sodium humate on membranepotential in internodal cells of Nitellopsis obtuse. Acta Societatis Botanicorum Poloniae, 52: 27,1-277.

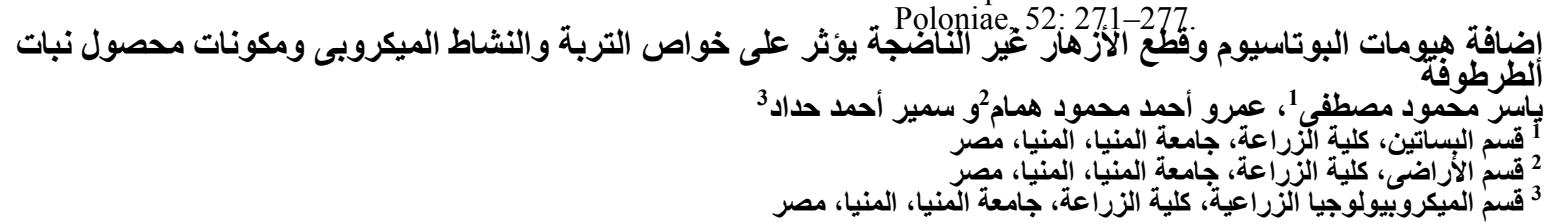

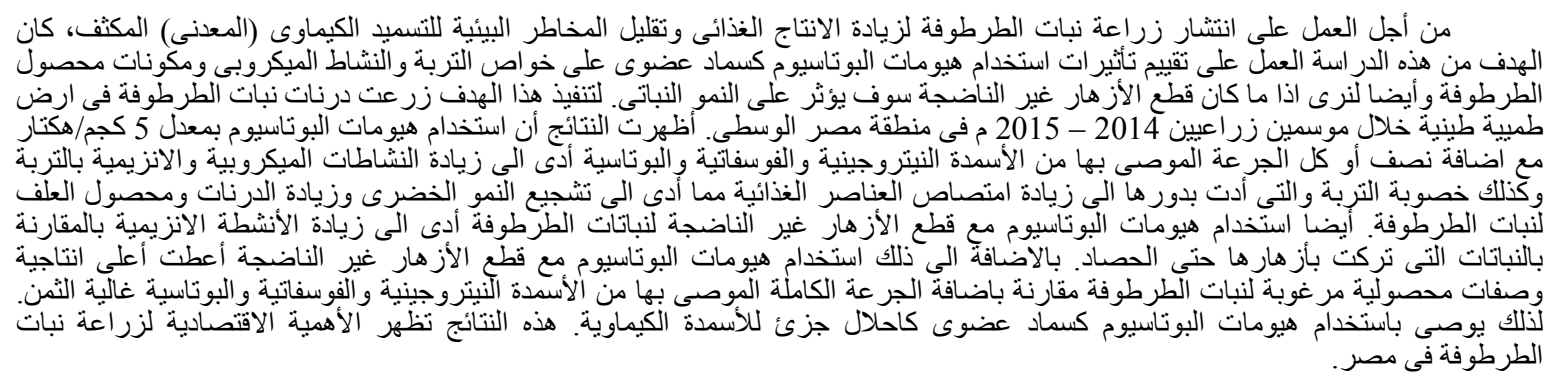

